\title{
Protein concentrates obtained from pig by-products using pH-shifting technique: a preliminary study
}

\author{
Claudine Garcia Chaves da Costa $^{1^{*}}$ (iD Marielle Maria de Oliveira Paula ${ }^{1}$ (iD \\ Armando Abel Massingue ${ }^{2}$ iD Robledo de Almeida Torres Filho ${ }^{3}$ \\ Eduardo Mendes Ramos ${ }^{1}$ (iD) João de Deus de Souza Carneiro ${ }^{1}$ (iD
}

${ }^{1}$ Departamento de Ciência dos Alimentos, Universidade Federal de Lavras (UFLA), 37200-000, Lavras, MG, Brasil. E-mail: claudine.gchaves@gmail.com. ${ }^{*}$ Corresponding author.

${ }^{2}$ Escola Superior de Desenvolvimento Rural, Universidade Eduardo Mondlane (UEM), Vilankulo, Mozambique. ${ }^{3}$ Instituto de Ciências Exatas e Tecnológicas, Universidade Federal de Viçosa (UFV), Campus Florestal, Florestal, MG, Brasil.

ABSTRACT: This study aimed to investigate the extraction and characterization of protein concentrates from pig by-products (heart, liver and kidneys) using the $\mathrm{pH}$-shifting technique. From the solubility profiles ( $\mathrm{pH} 2$ to 12 ), the protein extraction was performed at alkaline $\mathrm{pH}$ (10.0 to 11.5), obtaining two fractions: soluble (SC) and insoluble (IC). Higher protein content (71 to $77 \%$ ) and extractability (214 to 459 $\mathrm{mg} / \mathrm{g}$ ) were observed in heart and liver concentrates; whereas, for water holding capacity (WHC) the highest values (4.20 to $4.54 \mathrm{~g}$ water/g protein) were for the heart (SC) and kidney (SC and IC) concentrates. All concentrates had high emulsion stability and higher WHC than commercial protein extenders (whey and soybean). The concentrates obtained from the soluble fraction were redder (higher $a^{*}$ values and lower $h$ values) and darker (lower $L^{*}$ values) than insoluble fraction, especially heart and liver concentrates. Use of concentrates in sausage production slightly altered the color chroma $\left(C^{*}\right)$ of samples. It was concluded that the pig by-products protein concentrates had great potential of use as extenders in sausage production.

Key words: heart, kidney, liver, protein extensor, pH-shifting.

Concentrados proteicos obtidos de subprodutos suínos pela técnica de mudança do pH: um estudo preliminar

RESUMO: Objetivou-se investigar a extração e caracterização de concentrados proteicos obtidos de miúdos suínos (coração, figado e rins) pela técnica da solubilização isoelétrica. A partir das curvas de solubilidade (pH 2 a 12), a extração proteica foi realizada em pH alcalino (10,0 a 11,5), obtendo-se concentrados de duas frações: solúvel (CS) e insolúvel (CI). Maiores teores de proteina (71 a $77 \%)$ e solubilidade proteica (214 a $459 \mathrm{mg} / \mathrm{g}$ ) foram observados nos concentrados do coração e do figado, enquanto para a capacidade de reter água (CRA) os maiores valores (4,20 a 4,54 g água/g proteina) foram para os concentrados de coração (CS) e rins (CS e CI). Todos os concentrados apresentaram alta capacidade estabilizante e maior CRA do que extensores proteicos comerciais (soro de leite e soja). Os concentrados obtidos da fração solúvel eram mais vermelhos (maiores valores de $a^{*}$ e menores de h) e mais escuros (baixos valores de $L^{*}$ ) do que os insolúveis, especialmente os concentrados de coração e fígado. O uso dos concentrados na elaboração de salsichas alterou ligeiramente a saturação $\left(C^{*}\right)$ da cor das amostras. Concluiu-se que os concentrados de subprodutos suínos apresentam grande potencial de uso como extensores na elaboração de salsichas.

Palavras-chave: coração, figado, rins, extensor proteico, precipitação isoelétrica.

\section{INTRODUCTION}

In recent years, consumption of pork and further processed pork products has greatly increased in Brazil. Brazil's pork production from 2010 to 2017 increased from 2.3 to 3.8 million tons, being $81.5 \%$ of this production sold on the domestic market (ABPA, 2018). Considering this production, large quantities of by-products are generated at the slaughter process. Although, the pork consumption
(14.7 kg/per capita in 2017) is high in Brazil, offal's are little used for direct consumption, with most of the production destined for export $(10.8 \%$ of pork products exported in 2017) or for use in processed meat products.

Despite their low acceptance, offal's have relatively low cost, with high nutritional value, rich in proteins, and contribute to improve sensorially, technologically and increase the stability of processed products (TOLDRÁ et al., 2012). However, in 
Brazil it is also not common products with large offal's content, being their addition in traditional meat products, as in emulsified sausages, limited to $10 \%$ of the product. This leads to a surplus of these by-products, especially in the small-scale abattoir operating in regional and local markets, which are considered the main suppliers of pork.

Certainly, there is an underutilization of pork offal's such as liver, heart and kidney from which a more rational use is possible, especially due to their high protein content. One of the alternatives to increase the value of slaughterhouse by-products and make it more suitable for further processing would be to extract their proteins for use as functional ingredients in meat products, for instance as emulsifying or gelling agent, using similar technologies (SELMANE et al., 2008; HRYNETS et al., 2011).There are differences in functionality of proteins, which are closely related to their water holding capacity, emulsify capacity and gelling agent, being influenced by several factors, including protein source and process utilized. Therefore, a method that maintains protein functionality is necessary for the successful production of protein concentrates that have this desirable property (DEWITT et al., 2002).

Protein recovery using a $\mathrm{pH}$-shifting process it's a promising technique to recover meat proteins economically, at a relative high recovery rate and with improved functionality (HRYNETS et al., 2011). The process also known as isoelectric solubilization/precipitation (ISP) utilizes the principle that the solubility of a comminute protein-containing material homogenized in water is affected by the $\mathrm{pH}$ of the mixture. During ISP processing, meat proteins are first solubilized at low or high $\mathrm{pH}$ (acid or alkali), followed by precipitation at the isoelectric point to separate neutral and membrane lipids and further $\mathrm{pH}$ adjustment to the original meat $\mathrm{pH}$ (NOLSØE e UNDELAND, 2009; TAHERGORABI et al., 2011). Despite fish material, the ISP processing has been applied to beef (heart and lungs), pork (lungs) and poultry (dark chicken-meat and mechanically deboned chicken and turkey meat) processing byproducts (DEWITT et al., 2002; SELMANE et al., 2008; MOAYEDI et al., 2010; HRYNETS et al., 2011; TAHERGORABI et al., 2011).

Therefore, the overall objective of this study was to obtain and characterize protein concentrates from three pig by-products, namely liver, heart and kidney, by ISP process to initial screening for subsequent application as food ingredients.

\section{MATERIALS AND METHODS}

Fresh pig by-products (kidney, heart and liver), were purchased vacuum-packaged from a local abattoir and frozen $\left(-18{ }^{\circ} \mathrm{C}\right)$ until used. Commercial ingredients, whey protein concentrate (WPC, 54.82\% protein, $10.41 \%$ moisture, $3.47 \%$ fat, $5.18 \%$ ash and $26.13 \%$ carbohydrate; Tate \& Lyle Gemachom Tech, Juiz de Fora, MG, Brazil) and soy protein isolate (SPI; $84.88 \%$ protein, $9.47 \%$ moisture, $3.54 \%$ fat and $3.09 \%$ ash; New Nutrition, São Paulo. SP, Brazil), were used as reference materials.

In order to find the effect of different $\mathrm{pH}$ on the solubility of proteins in raw material, a solubility curve was created by each by-product as described by HRYNETS et al. (2011) with minor modifications. Six grams of raw material were homogenized (TE102; Tecnal Equipamentos Científicos, Brasil) with $300 \mathrm{~mL}$ deionized water (at $2{ }^{\circ} \mathrm{C}$ ) for approximately $2 \mathrm{~min}$. Aliquots of $30 \mathrm{~mL}$ of the homogenate were adjusted from $\mathrm{pH} 1.5$ to 12.0 in 0.5 intervals, using $\mathrm{HCl}$ or $\mathrm{NaOH}$ solutions $(0.2 \mathrm{M}$ or $1.0 \mathrm{M})$, with a $\mathrm{pH}$ meter (DM 20; Digimed, Brazil). The homogenate was centrifuged (Hettich EBA 21 centrifuge; Hettich $\mathrm{GmbH} \&$ Co.KG, Germany) at 5000×g for $15 \mathrm{~min}$. Protein concentration of each supernatant was determined using the Biuret colorimetric method, using bovine serum albumin (BSA, Sigma Chemical Co.) as standard. Protein solubility was expressed as milligram per milliliter $(\mathrm{mg} / \mathrm{mL})$. Two replications were carried out for each measurement. The $\mathrm{pH}$ in which the highest protein solubility was obtained was selected to obtain the proteins concentrates.

Protein extractions were conducted using a $\mathrm{pH}$-shifting with modification of the process described by HRYNETS et al. (2011). The alkaline-aided protein recovery was chosen after protein solubility profile analysis. For each by-product, $200 \mathrm{~g}$ of raw material were homogenized with cold $\left(2{ }^{\circ} \mathrm{C}\right)$ distilled water (1:5 meat: water ratio, w/v) in an industrial blender for $15 \mathrm{~min}$. The $\mathrm{pH}$ of each homogenate was adjusted by drop-wise addition of $\mathrm{NaOH} 0.2$ or $1.0 \mathrm{M}$ to reach the maximum solubility points with $\mathrm{pH}$ values of 10.0 (liver) and 11.5 (heart and kidney), as determined from the solubility profile. The homogenate was centrifuged (Heraeus ${ }^{\mathrm{TM}}$ Megafuge $^{\mathrm{TM}}$; Thermo Fisher Scientific, USA) at a rotational speed of $19,000 \times g$ for $20 \mathrm{~min}$ at $4{ }^{\circ} \mathrm{C}$. Upper layer (neutral lipids) was manually removed with the help of a stainlesssteel spatula and two fractions were obtained: the supernatant fraction (soluble proteins); and the pellet (insoluble proteins). It was decided not to carry out the isoelectric precipitation in the supernatant, which was 
conducted directly for lyophilization. Both fractions were frozen (at $-20{ }^{\circ} \mathrm{C}$ ) and subjected immediately to a lyophilization procedure in bench-top freeze drier (4.5L Labconco, USA). Dry concentrates were subjected to the ball milling process, for particle reduction and homogenization, vacuum packed and stored (at room temperature) until analysis.

Six protein concentrate were obtained: heart supernatant concentrate (HSC); heart pellet concentrate (HPC); liver supernatant concentrate (LSC); liver pellet concentrate (LPC); kidney supernatants concentrate (KSC); and kidney pellet concentrate (KPC). The by-products raw material and the concentrates were characterized according to its proximate composition (moisture, protein, fat and ash), by the AOAC procedures (AOAC, 2012).

The protein extractability was evaluated according to modifications of the procedures described by NOLLET e TOLDRÁ (2011). About $0.2 \mathrm{~g}$ of each protein concentrate was diluted in $10 \mathrm{~mL}$ of $0.05 \mathrm{M}$ phosphate buffer solution ( $\mathrm{pH} 7.4)$, vortexed and centrifuged (EBA 21; Hettich $\mathrm{GmbH} \&$ Co.KG, Germany) at 5,000 $\times g$ for $15 \mathrm{~min}$. Protein concentration of the supernatant was determined by Biuret method and water-soluble proteins (WSP) expressed as mg protein/g sample. The pellet was suspended in 10 $\mathrm{mL}$ of $0.05 \mathrm{M}$ phosphate buffer (pH 7.4) with $1.1 \mathrm{M}$ $\mathrm{NaCl}$, vortexed and centrifuged at $5,000 \times \mathrm{g}$ for 15 $\min$. The protein concentration of the new supernatant was determined by Biuret method and the salt-soluble proteins (SSP) expressed as mg protein/g sample.

The water holding capacity (WHC) was evaluated by modification of the centrifuge method described by WANG e ZAYAS (1991). About $1.0 \mathrm{~g}$ of the pig by-products concentrates, soy protein isolate (SPI) and whey protein concentrate (WPC) were dissolved in $25 \mathrm{~mL} 0.1 \mathrm{M}$ phosphate buffer ( $\mathrm{pH}$ 6.5), vortexed and centrifuged (EBA 21; Hettich GmbH \& Co.KG, Germany) at $2,300 \times g$ for $10 \mathrm{~min}$. The supernatant was carefully removed and the pellet (hydrated protein) weighed. The WHC was calculated as the difference between hydrated weight and original weight of sample, being expressed as $\mathrm{g}$ water/g and as $\mathrm{g}$ water/g protein.

The CIE lightness $\left(L^{*}\right)$, redness $\left(a^{*}\right)$ and yellowness $\left(b^{*}\right)$ were obtained from the specular light excluded (SCE) mode readings using a spectrophotometer (CM-700d; Konica Minolta, USA), with $8 \mathrm{~mm}$ aperture port, illuminant D65 and $10^{\circ}$ stander observer. The pig by-products protein concentrates and the commercial proteins ingredients (WPC and SPI) were placed in Petri glass dishes and the analysis was performed at six different points on the surface. The color coordinates were also expressed on the CIELCH system, with chroma $\left(C^{*}\right)$ and hue angle $(h)$ being calculated as (RAMOS e GOMIDE, 2017): $C^{*}=\left(a^{* 2}+b^{* 2}\right)^{0.5}$ and $h=\tan ^{-1}\left(b^{*} / a^{*}\right)$.

To evaluate the practical application of the pig by-product concentrates in meat products, an emulsion-type sausage model was elaborated according to MASSINGUE et al. (2018). Sausages (62\% mechanically deboned poultry meat, $13 \%$ pork meat, $20.4 \%$ water, $2 \%$ salt, $0.5 \%$ sodium tripolyphosphate, $0.02 \%$ sodium nitrite and $0.1 \%$ sodium erythorbate) were prepared with $2 \%$ of each pig by-product protein concentrate, WPC or SPI. The raw batter mixture was used to evaluate emulsion stability and the cooked sausage obtained to the instrumental color evaluations.

Stability of the emulsion was evaluated by HUGHES et al. (1997), with minor modifications. About $25 \mathrm{~g}$ of the raw emulsion batter was weight into $50 \mathrm{~mL}$ polyethylene centrifuge tubes, centrifuged (EBA 21; Hettich GmbH \& Co.KG, Germany) at 3,000 $\times g$ for $1 \mathrm{~min}$ to compact the batter. The tubes were heated in a water bath $\left(\right.$ at $70{ }^{\circ} \mathrm{C}$ ) for $30 \mathrm{~min}$, cooled in tap water and again centrifuged at $3,000 \times g$ for $3 \mathrm{~min}$. All tubes were then dropped for $30 \mathrm{~min}$ in pre-weighed porcelain crucibles, to collect all released supernatant (fluid), which were dried overnight at $105{ }^{\circ} \mathrm{C}$. The volumes of total expressible fluid (TEF) and the percentage fat ( $\%$ Fat $)$ were calculated as follows: $\mathrm{TEF}=($ Weight of crucible + fluid $)-($ Weight of empty crucible); $\% \mathrm{TEF}=100 \times \mathrm{TEF} /$ sample weight; and $\%$ Fat $=100 \times[($ Weight of crucible + dried fluid $)-$ (Weight of empty crucible)]/TEF.

The CIE color was performed on cooked samples obtained after the emulsion stability analysis. Samples were cut crosswise at different points, obtaining three cylinders of $2.0 \mathrm{~cm}$ height, and the color indices obtained by three readings at different points of the internal surface of each cylinder as described for the protein concentrates.

The experiment was carried out in a completely randomized design with one factor, containing six (pig by-products concentrates) or eight (pig by-products concentrates plus WPC and SPI) levels, and three replicates. Main effects were evaluated by F-test (ANOVA) and means were separated using Tukey's test $(\mathrm{P}<0.05)$. Statistical analyzes were performed in the SAS software (Statistical Analysis System, Institute Inc., Cary, NC, USA).

\section{RESULTS AND DISCUSSION}

The protein solubility profile for pig liver, heart and kidney with $\mathrm{pH}$ ranging from 1.5 to 12.0 are described in the figure 1. The lowest solubility (or 
highest precipitation) was observed in the $\mathrm{pH}$ range of 4.5 to 5.5 , with lower values recorded by heart at $\mathrm{pH} 5.5$ $(0.38 \mathrm{mg} / \mathrm{mL}$ ), followed by kidney at $\mathrm{pH} 4.5-5.0$ (mean of $0.83 \mathrm{mg} / \mathrm{mL}$ ) and by liver at $\mathrm{pH} 5.0$ (mean of $1.18 \mathrm{mg}$ / $\mathrm{mL}$ ). At the isoelectric point, protein-water interactions are minimal, whereas aggregates of weak proteinprotein hydrophobic interactions are present, causing precipitation of proteins (FENNEMA, 1996). The $\mathrm{pH}$ observed for the lower solubility of the by-products is close to the isoelectric points ( $\mathrm{pH}$ 5.5) observed for the majority of muscle proteins (XIONG, 2018).

Notably, an increase in solubility was observed during acidification or alkalization of the extraction media. The protein solubility was higher at higher $\mathrm{pH}$ values for liver $(5.23 \mathrm{mg} / \mathrm{mL}$ between $\mathrm{pH}$ 9.0 and 12.0$)$ and kidney $(3,81 \mathrm{mg} / \mathrm{mL}$ between 9.0 and 10.0) than at lower $\mathrm{pH}$ values $(2.89 \mathrm{mg} / \mathrm{mL}$ liver and $3.53 \mathrm{mg} / \mathrm{mL}$ kidney, both at $\mathrm{pH} 2.5$ ). For heart; however, the highest protein solubility (mean of $3.42 \mathrm{mg} / \mathrm{mL}$ ) was observed in low (2.0) and high (12.0) $\mathrm{pH}$ values. These differences in the protein solubility profile might be attributed to differences in the ionizable groups of the polypeptide chains of proteins (FENNEMA, 1996) of each by-product. Based on the solubility study, alkalineaided protein recovery ( $\mathrm{pH}$ between 10.0 and 12) were selected for the protein extraction.

Table 1 summarize results from physicochemical and technological characterization of the pig by-products concentrates. Concentrates with higher protein content were obtained from sources that contained lower moisture $(75.72 \%$ heart and $73.90 \%$ liver) and highest protein content $(20.76 \%$ heart and $22.57 \%$ liver) and, except for the kidney concentrates, higher protein was retained in the soluble fraction. Higher amounts of insoluble stromal proteins (collagen content) in kidney (OCKERMAN e HANSEN, 2000) may have contributed to the absence of different between fractions of protein concentrates for this raw material. Moreover, lower values of protein content for kidney concentrates seems to be due to the lower values of protein in raw material $(16.23 \%)$ and greater retention of water (due to the higher moisture content $-81.08 \%$ ) after drying. In the raw material, higher fat contents were observed in the liver $(3.81 \%)$, followed by kidney (3.27\%) and heart (2.57\%).

In relation to the ash content, higher values were observed in the heart $(1.22 \%)$ than in the kidney and liver raw material samples (mean of $0.82 \%$ ). However, a greater concentration in the soluble fraction of the concentrates of heart and kidney was observed. CHEN et al. (2007) demonstrated that basic treatments during solubilization of trout filleting processing by-products (contained bones with left-over fish meat, skin, scales, and fins) yielded protein concentrate with less minerals $(\mathrm{Mg}$, $\mathrm{Ca}$, and $\mathrm{P}$ ) than the insoluble fractions. However,

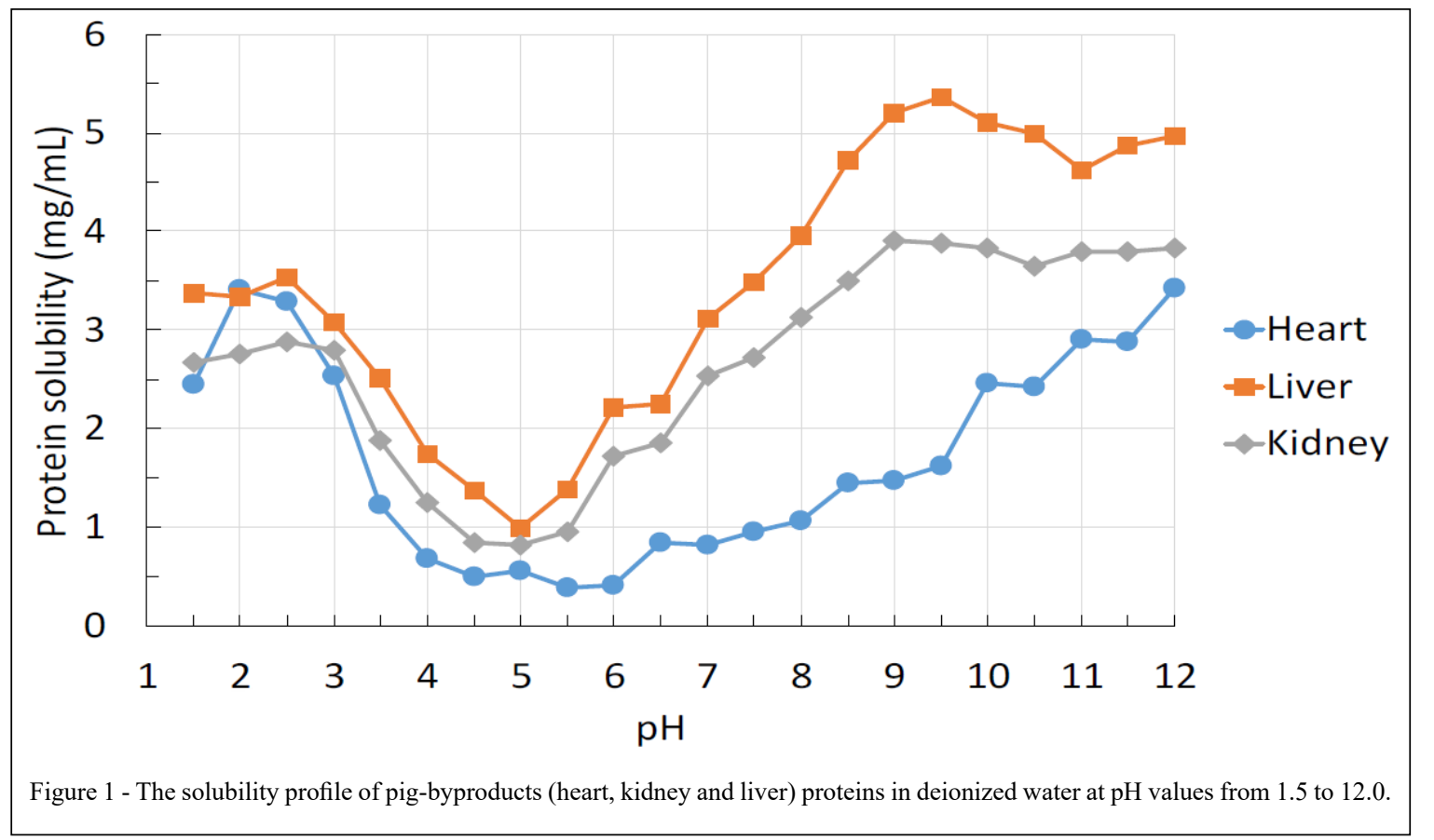

Ciência Rural, v.49, n.6, 2019. 
Table 1 - Physicochemical and technological characteristics of pig by-products protein concentrates and its effects in sausage formulation.

\begin{tabular}{|c|c|c|c|c|c|c|c|c|c|}
\hline & \multicolumn{3}{|c|}{------- Soluble fraction ------- } & \multicolumn{3}{|c|}{---------- Insoluble fraction --------- } & \multirow[b]{2}{*}{ WPC } & \multirow[b]{2}{*}{ SPI } & \multirow[b]{2}{*}{ SEM } \\
\hline & $\begin{array}{c}\text { Heart } \\
\text { (HSC) }\end{array}$ & $\begin{array}{c}\text { Kidney } \\
(\mathrm{KSC})\end{array}$ & $\begin{array}{l}\text { Liver } \\
\text { (LSC) }\end{array}$ & $\begin{array}{l}\text { Heart } \\
(\mathrm{HPC})\end{array}$ & $\begin{array}{c}\text { Kidney } \\
\text { (KPC) }\end{array}$ & $\begin{array}{l}\text { Liver } \\
(\mathrm{LPC})\end{array}$ & & & \\
\hline \multicolumn{10}{|c|}{ 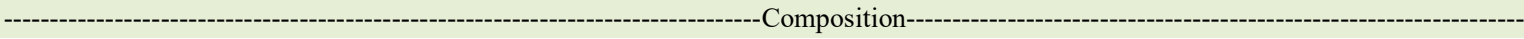 } \\
\hline Moisture (\%) & $9.56^{c}$ & $14.78^{a}$ & $8.90^{c}$ & $8.20^{c}$ & $11.50^{b}$ & $8.19^{c}$ & - & - & 0.58 \\
\hline Protein $(\%)$ & $77.30^{a}$ & $67.45^{d}$ & $73.48^{b}$ & $73.51^{b}$ & $66.22^{d}$ & $70.32^{c}$ & - & - & 0.94 \\
\hline Fat $(\%)$ & $5.51^{c}$ & $10.46^{b}$ & $14.81^{a}$ & $14.80^{a}$ & $14.18^{a}$ & $14.87^{a}$ & - & - & 0.88 \\
\hline Ash (\%) & $8.98^{a}$ & $8.19^{a b}$ & $4.85^{c}$ & $3.92^{c}$ & $6.94^{b}$ & $4.84^{c}$ & - & - & 0.46 \\
\hline \multicolumn{10}{|c|}{ 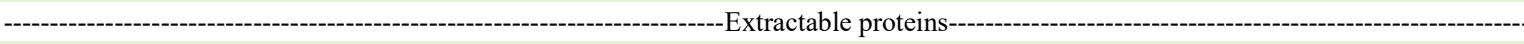 } \\
\hline Total (mg/g) & $339^{b}$ & $177^{d}$ & $460^{a}$ & $249^{c}$ & $114^{e}$ & $214^{c d}$ & - & - & 28 \\
\hline WSP $(\mathrm{mg} / \mathrm{g})$ & $180^{b}$ & $123^{c}$ & $280^{a}$ & $193^{b}$ & $76^{c}$ & $150^{b}$ & - & - & 16 \\
\hline $\mathrm{SSP}(\mathrm{mg} / \mathrm{g})$ & $159^{a}$ & $54^{c}$ & $179^{a}$ & $56^{c}$ & $38^{c}$ & $64^{b}$ & - & - & 14 \\
\hline \multicolumn{10}{|c|}{ 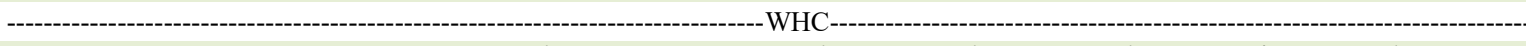 } \\
\hline (g water/g sample) & $3.30^{a}$ & $2.83^{b}$ & $1.67^{e}$ & $2.63^{b c}$ & $2.92^{b}$ & $2.28^{c d}$ & $0.99^{f}$ & $2.24^{d}$ & 0.15 \\
\hline (g water/g protein) & $4.27^{a}$ & $4.20^{a}$ & $2.27^{a}$ & $3.58^{a}$ & $4.54^{a}$ & $3.24^{a}$ & $1.85^{d}$ & $2.63^{c}$ & 0.20 \\
\hline \multicolumn{10}{|c|}{ 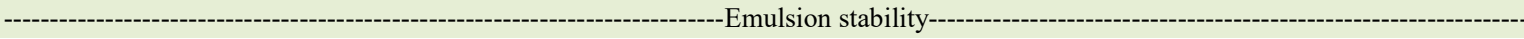 } \\
\hline$\% \mathrm{TEF}$ & $0.26^{b}$ & $0.52^{b}$ & $0.45^{b}$ & $0.30^{b}$ & $0.66^{b}$ & $0.54^{b}$ & $0.35^{b}$ & $1.21^{a}$ & 0.07 \\
\hline$\%$ FAT & $8.94^{a}$ & $5.88^{b}$ & $8.76^{a}$ & $8.62^{a}$ & $6.76^{a b}$ & $6.88^{a b}$ & $8.33^{a}$ & $5.51^{b}$ & 0.34 \\
\hline \multicolumn{10}{|c|}{ 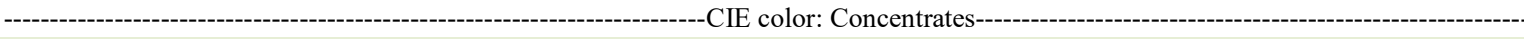 } \\
\hline Luminosity $\left(L^{*}\right)$ & $60.21^{h}$ & $70.88^{f}$ & $64.07^{g}$ & $76.34^{d}$ & $78.35^{c}$ & $73.19^{e}$ & $92.39^{b}$ & $99.07^{a}$ & 2.58 \\
\hline Redness $\left(a^{*}\right)$ & $15.42^{a}$ & $10.08^{c}$ & $13.41^{b}$ & $9.11^{e}$ & $8.90^{e}$ & $9.51^{d}$ & $4.74^{f}$ & $2.99^{g}$ & 0.79 \\
\hline Yellowness $\left(b^{*}\right)$ & $14.14^{e}$ & $18.19^{b}$ & $19.33^{a}$ & $16.08^{c}$ & $18.32^{b}$ & $18.97^{a}$ & $15.77^{c}$ & $15.09^{d}$ & 0.38 \\
\hline Chrome $\left(C^{*}\right)$ & $20.92^{b}$ & $20.80^{b c}$ & $23.52^{a}$ & $18.48^{d}$ & $20.37^{c}$ & $21.22^{b}$ & $14.46^{e}$ & $15.38^{f}$ & 0.53 \\
\hline Hue angle $\left(h^{\circ}\right)$ & $42.53^{f}$ & $61.00^{d}$ & $55.26^{e}$ & $60.47^{d}$ & $64.09^{c}$ & $63.38^{c}$ & $73.28^{b}$ & $78.81^{a}$ & 2.14 \\
\hline \multicolumn{10}{|c|}{ 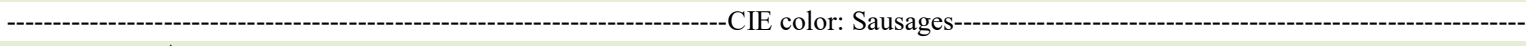 } \\
\hline Luminosity $\left(L^{*}\right)$ & 61.95 & 62.76 & 61.66 & 63.44 & 64.27 & 61.69 & 64.49 & 64.21 & 0.32 \\
\hline Redness $\left(a^{*}\right)$ & $6.08^{a b}$ & $5.87^{a b}$ & $7.04^{a}$ & $5.78^{b}$ & $5.31^{b}$ & $5.93^{b}$ & $5.93^{b}$ & $5.93^{b}$ & 0.17 \\
\hline Yellowness $\left(b^{*}\right)$ & 18.08 & 16.94 & 18.21 & 17.27 & 17.87 & 17.90 & 16.40 & 16.98 & 0.19 \\
\hline Chrome $\left(C^{*}\right)$ & $19.08^{a b}$ & $17.98^{a b}$ & $19.55^{a}$ & $18.22^{a b}$ & $18.64^{a b}$ & $18.86^{a b}$ & $18.86^{b}$ & $18.86^{b}$ & 0.19 \\
\hline Hue angle $\left(h^{\circ}\right)$ & 71.40 & 70.73 & 68.75 & 71.53 & 73.44 & 71.63 & 71.82 & 74.57 & 0.54 \\
\hline
\end{tabular}

$\mathrm{WPC}=$ whey protein concentrate; SPI = soy protein isolate; $\mathrm{S} . \mathrm{M} . \mathrm{E}=$ standard error of means; WSP $=$ water-soluble proteins; SSP $=$ saltsoluble proteins; $\mathrm{WHC}=$ water holding capacity; $\% \mathrm{TEF}=$ total expressive fluid; and $\% \mathrm{FAT}=$ fat content in expressible fluid.

${ }^{a-h}$ Means followed by different letters in the same row differ $(\mathrm{P}<0.05)$ by Tukey's test.

in the present research, it should be considered that the raw material used to obtain the concentrates is richer in heme iron, which are associated with watersoluble heme pigments (hemoglobin and myoglobin) (RAMOS e GOMIDE, 2017). Therefore, this would explain the higher values in the soluble fraction. From the nutritional point of view, it is of interest to assess how these minerals are separated from the recovered protein during the $\mathrm{pH}$-shifting processing.

The total extractable proteins and its fractions (water- and salt-soluble proteins) were affected $(\mathrm{P}<0.05)$ by the treatments. Extractability is an important property since the amount of protein available in the solution affects the functional properties expected from proteins (HRYNETS et al.,
2011). Overall, the total extractable proteins were higher in the soluble concentrates from by-products with highest protein content (liver and heart). Also, higher water-soluble proteins (WSP) were observed in all concentrates than salt-soluble proteins (SSP), which confirmed that a sizeable amount of WSP is recovered, during $\mathrm{pH}$-shifting processes (HRYNETS et al., 2011; MATAK et al., 2015). Liver concentrate from soluble fraction (LSC) had higher values of WSP and, together with HSC, higher values of SSP. For both fractions, significant lower values were observed for kidney concentrates, which may also be due to the greater presence of insoluble stromal proteins in this by-product. Moreover, there was no difference in the WSP extractability between concentrate fractions 
for each type of by-products, but higher SSP extract ability was observed in the soluble fraction of heart and liver concentrates; with the same behavior as observed for the protein content.

Contrary to that observed for total protein extractability, higher protein content did not guarantee a higher WHC; although, the highest WHC were observed in the HSC when expressed as $\mathrm{g}$ water/g sample. Taking into account the protein content of the concentrate, higher values of WHC ( $g$ water/ $\mathrm{g}$ protein) were observed in HSC and in the kidney concentrates (both fractions), and it was also observed in the LPC for the insoluble fraction. These difference between treatments can be explained by the different degrees of protein denaturation, which may have occurred during the extraction or freezedrying process, affecting the surface hydrophobic (protein-protein) and hydrophilic (protein-solvent) interactions of proteins (FENNEMA, 1996).

However, it is interesting to note that all pig by-products concentrates had WHC higher $(\mathrm{P}<0.05)$ than the whey concentrate (WPC) and, except for the LSC, than the soy protein isolate (SPI). Moreover, the emulsion stability (total expressive fluid; \% TEF) of the elaborated sausages was not influenced $(\mathrm{P}>0,05)$ by the type of raw material or extraction fraction, being not different from sausages elaborated with WPC, but higher (lower \% TEF values) than SPI. Emulsion stability differences between the by-products concentrate were observed only in relation to the amount of fat (\% FAT) present in the exudate. These results suggested that the by-products concentrates had higher potential of use as extensors in food products, with good emulsify capacity.

Since in the $\mathrm{pH}$-shifting process is expected extraction of a large amounts of sarcoplasmic proteins, among then the heme pigments (myoglobin and hemoglobin), the color of the concentrates becomes very important when applied in food. As expected, all color indexes $(\mathrm{P}<0,05)$ were affected by treatments. Overall, concentrates obtained from the soluble fraction are redder (higher $a^{*}$ values and lower $h$ values) and darker (lower $L^{*}$ values) than the insoluble ones, which can be justified by the fact that the sarcoplasmic proteins are readily soluble in water and low ionic strength solutions (XIONG, 2018). In this sense, it is also justifiable that the reddest and darkest concentrates are those obtained from sources with higher contents of heme pigments, namely heart and liver (OCKERMAN e HANSEN, 2000).

All pig by-products concentrates had redder and darker color than the commercial extensors WHC and SIP commonly used in food products and these differences are illustrated in figure 2a. Nerveless, despite these differences in the concentrate's colors, color of sausages on which they were used was very little affected by the type of concentrate used. Only redness $\left(a^{*}\right)$ and chroma $\left(C^{*}\right)$ were affected $(\mathrm{P}<0,05)$ by the treatments, but these differences are probably imperceptible (as can be observed in figure $2 b$ ).

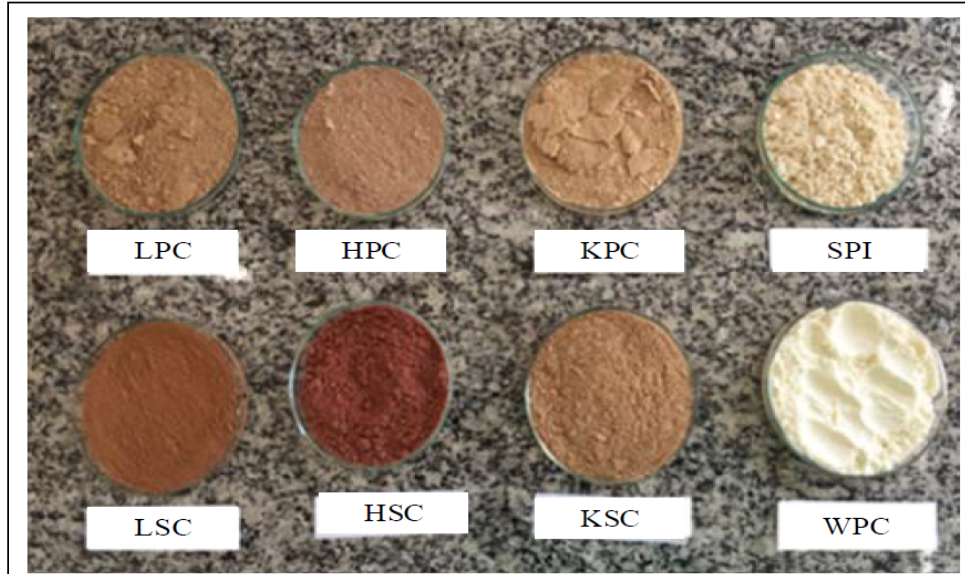

(a) Protein concentrates

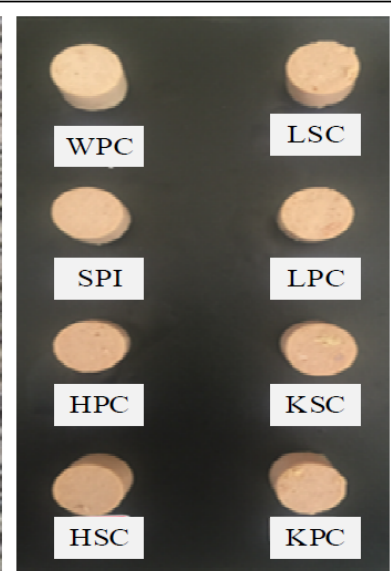

(b) Sausages

Figure 2 - Images of protein concentrates used in the experiment and of emulsify-type sausages elaborated with these concentrates. $\mathrm{HSC}=$ heart supernatant (soluble) concentrate; $\mathrm{HPC}=$ heart pellet (insoluble) concentrate; LSC $=$ liver supernatant concentrate; $\mathrm{LPC}=$ liver pellet concentrate; $\mathrm{KSC}=$ kidney supernatant concentrate; KPC $=$ kidney pellet concentrate WPC $=$ whey protein concentrate; and SPI $=$ soy protein isolate. 


\section{CONCLUSION}

Protein concentrate extracts processed from pig offal's (liver, heart and kidney)is an enriched protein content above $60 \%$, with water holding capacity and emulsion stability equal to or better than the commercial protein extensor used as ingredient in meat processing, namely soybean protein isolate and whey protein concentrate. The color of the by-products protein concentrates seems do not affected the color of the meat product in which it is used.

Thus, it can be concluded that the production of protein concentrates from pig by-product is an effective alternative for its harnessing and added commercial value, but their development should be improved and other characteristics (nutritional, sensory and even technological) evaluated.

\section{ACKNOWLEDGEMENTS}

This study was financed in part by the and Coordenação de Aperfeiçoamento de Pessoal de Nível Superior (CAPES) for the scholarship grants to the first (Master Degree) author. The authors would like to thank also the Fundação de Amparo e Pesquisa de Minas Gerais (FAPEMIG) and the Conselho Nacional de Desenvolvimento Científico e Tecnológico $(\mathrm{CNPq})$ for the financial support.

\section{DECLARATION OF CONFLICT OF INTERESTS}

The authors declare no conflict of interest. The founding sponsors had no role in the design of the study; in the collection, analyses, or interpretation of data; in the writing of the manuscript, and in the decision to publish the results.

\section{AUTHORS' CONTRIBUTIONS}

All authors contributed equally for the conception and writing of the manuscript. All authors critically revised the manuscript and approved of the final version.

\section{REFERENCES}

ABPA. Relatório anual ABPA 2018. São Paulo, SP, 2018 Available from: <http://abpa-br.com.br/setores/avicultura/ publicacoes/relatorios-anuais $>$. Accessed: Dec. 15, 2018.

AOAC. Official methods of analysis of AOAC International. 19th ed. Gaithersburg, MD: Association of Official Analytical Chemists, 2012. 1298p.

CHEN, Y.-C.; et al. Amino acid, Fatty Acid, and Mineral Profiles of Materials Recovered from Rainbow Trout (Oncorhynchus mykiss) Processing By-Products Using Isoelectric Solubilization/Precipitation. Journal of Food Science, v.72, n.9, p.C527-C535, 2007. Available from: $<$ https://doi.org/10.1 111/j.1750-3841.2007.00522.x>. Accessed: Nov. 12, 2018. doi: 10.1111/j.1750-3841.2007.00522.x

DEWITT, C. A. M. et al. Protein extraction from Beef Heart using Acid Solubilization. Journal of Food Science, v.67, n.9, p.3335-3341, 2002. Available from: <https://doi. org/10.1111/j.1365-2621.2002.tb09588.x.>. Accessed: Nov. 03, 2018. doi: 10.1111/j.1365-2621.2002.tb09588.x.

FENNEMA, O. R. Food Chemistry, Third Edition. ed. New York: Marcel Dekker, Inc., 1996.

HRYNETS, Y. et al. Comparative study on the effect of acid- and alkaline-aided extractions on mechanically separated turkey meat (MSTM): Chemical characteristics of recovered proteins. Process Biochemistry, v.46, n.1, p.335-343, 2011. Available from: $<$ https:// doi.org/10.1016/j.procbio.2010.09.006>. Accessed: Oct. 21, 2018. doi: 10.1016/j.procbio.2010.09.006.

HUGHES, E. et al. Effects of fat level, oat fibre and carrageenan on frankfurters formulated with 5, 12 and $30 \%$ fat. Meat Science, v.45, n.3, p.273-281, 1997. Available from: $<$ https://doi. org/10.1016/S0309-1740(96)00109-X>. Accessed: Oct. 21, 2018. doi: 10.1016/S0309-1740(96)00109-X.

MASSINGUE, A. A. et al. Effect of mechanically deboned poultry meat content on technological properties and sensory characteristics of lamb and mutton sausages. Asian-Australas Journal of Animal Science, v.31, n.4, p.576-584, 2018. Available from: <https://doi.org/10.5713/ajas.17.0471>. Accessed: Sep. 28, 2018. doi: 10.5713/ajas.17.0471.

MATAK, K. E. et al. A review: Protein isolates recovered by isoelectric solubilization/precipitation processing from muscle food by-products as a component of nutraceutical foods. Food Research International, v.77, p.697-703, 2015. Available from: $<$ https://doi.org/10.1016/j.foodres.2015.05.048>. Accessed: Nov. 12, 2018. doi: 10.1016/j.foodres.2015.05.048.

MOAYEDI, V. et al. Alkali-aided protein extraction of chicken dark meat: Composition and stability to lipid oxidation of the recovered proteins. Poultry Science, v.89, n.4, p.766-775, 2010. Available from: <https://doi.org/10.3382/ps.2009-00494>. Accessed: Nov. 14, 2018. doi: 10.3382/ps.2009-00494.

NOLLET, L. M. L.; TOLDRÁ, F. Handbook of analysis of edible animal by-products. ed. Boca Raton : Taylor \& Francis, 2011

NOLSØE, H.; UNDELAND, I. The acid and Alkaline Solubilization Process for the Isolation of Muscle Proteins: State of the Art. Food and Bioprocess Technology, v.2, n.1, p.1-27, March 01 2009. Available from: <https://link.springer.com/ article/10.1007/s11947-008-0088-4>. Accessed: Nov. 18, 2018. doi: 10.1007/s11947-008-0088-4

OCKERMAN, H. W.; HANSEN, C. L. Animal by-product processing \& utilization. ed. Boca Raton: CRC Press, 2000. 523p.

RAMOS, E. M.; GOMIDE, L. A. M. Avaliação da Qualidade de Carnes: Fundamentos e Metodologias. 2a ed. Viçosa: Editora UFV, 2017. 473p.

SELMANE, D. et al. Extraction of proteins from slaughterhouse by-products: Influence of operating conditions on functional properties. Meat Science, v.79, n.4, p.640-647, 2008. Available

Ciência Rural, v.49, n.6, 2019. 
from: <https://doi.org/10.1016/j.meatsci.2007.10.029>. Accessed: Nov. 12, 2018. doi: 10.1016/j.meatsci.2007.10.029.

TAHERGORABI, R. et al. Effect of isoelectric solubilization/ precipitation and titanium dioxide on whitening and texture of proteins recovered from dark chicken-meat processing byproducts. LWT - Food Science and Technology, v.44, n.4, p.896-903, 2011. Available from: <https://doi.org/10.1016/j. lwt.2010.10.018>. Accessed: Sep. 21, 2018. doi: 10.1016/j. lwt.2010.10.018.

TOLDRÁ, F. et al. Innovations in value-addition of edible meat by-products. Meat Science, v.92, n.3, p.290-
296, 2012. Available from: <https://doi.org/10.1016/j. meatsci.2012.04.004>. Accessed: Nov. 28, 2018. doi: 10.1016/j. meatsci.2012.04.004.

WANG, C. R.; ZAYAS, J. F. Water Retention and Solubility of Soy Proteins and Corn Germ Proteins in a Model System. Journal of Food Science, v.56, n.2, p.455-458, 1991. Available from: $<$ https:// doi.org/10.1111/j.1365-2621.1991.tb05302.x>. Accessed: Nov. 12, 2018 doi: 10.1111/j.1365-2621.1991.tb05302.x.

XIONG, Y. L. 5 - Muscle proteins. In: YADA, R. Y. (Ed.). Proteins in Food Processing (Second Edition): Woodhead Publishing, 2018. p.127-148. 